\title{
Public Opinion in Magelang Region on Smoke Free Law
}

\author{
Heni Setyowati Esti Rahayu ${ }^{1 *}$, Retno Rusdjijati², Rochiyati Murniningsih ${ }^{3 *}$, \\ Siti Nur Hikmah ${ }^{4 *}$, Heniyatun ${ }^{5^{*}}$, Eny Zuhriyah ${ }^{6 *}$, Nugroho Agung Prabowo ${ }^{7 *}$ \\ ${ }^{1234567}$ Muhammadiyah Tobacco Control Center UM Magelang, \\ Jalan Mayjend Bambang Soegeng Km.5, Magelang \\ *E-mail: henisetyowati@ummgl.ac.id \\ https://doi.org/10.30787/gaster.v19i1.590
}

\section{ARTICLE INFO}

Keywords: Regulation;

Smoke Free Law

\section{ABSTRACT}

Indonesia is the country with the highest number of smokers in ASEAN. There are already several regulations to create smoke free law, but only a few have local regulations on smoke free law. This study aims to explore public opinion on the importance of smoke free law regulation. The study used a descriptive design with a sample of 356 people who live in the City and District of Magelang. Data were analyzed with descriptive statistics including mean, standard deviation, number and percentage. The results showed that $34.3 \%$ of respondents smoke. Knowledge of respondents about the dangers of smoking $86 \%$ have high knowledge. Most respondents (87\%) smoke free law regulation support. $56 \%$ of respondents stated that advertisements influence smoking behavior and most respondents saw cigarette advertisements on television. Conclusion: the community has supported the existence of smoke free law regulations so that the Government is expected to immediately realize it to avoid increasing the number of smokers in Indonesia

\section{INTRODUCTION}

Indonesia is the country with the highest number of smokers in ASEAN with $46.16 \%$ percentage, Philippines (16.62\%), Vietnam (14.1\%), Myanmar (8.73\%), Thailand (7.74\%), Malaysia (2.90\%),
Cambodia (2.07\%), Laos (1.23\%), Singapore $(0.39 \%)$ and Brunei (0.04\%) (1). Even the prevalence of smokers under the age of 18 continues to increase. The increase occurred from 7.2 percent to 8.8 percent in 2015 (2). A third of Indonesians today are smokers. Even 
smokers under the age of 15 in Indonesia are currently among the largest in the world after China and India (3).

Smoking behavior contributes significantly to the cause of non-communicable diseases compared to other risk factors. A smoker has a two to four times greater risk of developing coronary heart disease. The results showed that smoking caused 131,502 cancer incidents and 105,830 cancer deaths in ASEAN countries in 2012. Merokok contributed $28.4 \%$ (43.3\% in men and $8.5 \%$ in women) from cancer incidence and $30.5 \%$ (44.2\% in men and $9.4 \%$ in women) from cancer deaths in ASEAN (4).

Government policy to control cigarettes is contained in Law No. 36 year 2009 on Health, PPNo. 109 Year 2012 on Safeguarding Tobacco Products for Health, Decree No. 28 Year 2013 on the Inclusion of Health Warnings, Permenkes No. 40 Year 2013 on Road Map of Controlling the Impact of Cigarette Consumption for Health. Undang health law No. 36 year 2009 Article 115 paragraph (2) states that the local government is obliged to establish a non-smoking area (smoke free law) in its territory. While in Article 115 paragraph (1) referred to nonsmoking areas, among others: a) health care facilities, b) places of teaching and learning process, c) where children play, d) places of worship, e) public transportation, f) workplaces, and g) public places and other designated places. But the reality is that there are not many areas that have regulations about non-smoking areas. In Central Java there are 35 cities/districts, but only 14 have a Smoke free law Regulation.

Policies for cigarette control have existed, but in reality there are still many cities and districts that do not have a Regional Regulation of smoke free law so it is necessary to conduct a study on the needs of the Regional Government of smoke free law to identify the need for the creation of a Smoke free law Regulation. The purpose of this research is to identify public opinion about the needs of the smoke free law Regulation.

\section{METHODS AND MATERIALS}

This research is a descriptive research to find out the opinions of the public about the Regional Government of Smoke free law. However, some qualitative data is used to clarify the explanation from the community about the need for the smoke free law Regulation. The population in this study was all people in city and regency of Magelang. The sample of this study was 356 people who live in the City and District of 
Magelang with the criteria of being willing to become respondents at the age of 20-49 years.

Data analysis was carried out univariately to describe the characteristics of each variable using a central tendency such as mean, number and percentage.

\section{RESULTS AND DISCUSSIONS}

Table 1. Characteristics of Respondents $(n=356)$

\begin{tabular}{|c|c|c|c|c|c|}
\hline No & Variable & Mean & $\mathrm{Sd}$ & Amount & Percentage \\
\hline 1 & Age & 34,2 & 14,49 & & \\
\hline \multirow[t]{3}{*}{2} & Gender & & & & \\
\hline & a. Male & & & 191 & 53,7 \\
\hline & b. Female & & & 165 & 46,3 \\
\hline \multirow[t]{3}{*}{3} & Education Level & & & & \\
\hline & $\begin{array}{l}\text { a. Low (Elementary and Junior High } \\
\text { School) }\end{array}$ & & & 111 & 31,2 \\
\hline & $\begin{array}{l}\text { b. High School (Senior high scholl } \\
\text { and college) }\end{array}$ & & & 245 & 68,8 \\
\hline \multirow[t]{3}{*}{4} & Smoking Status & & & & \\
\hline & a. Smoking & & & 122 & 34,3 \\
\hline & b. No smoking & & & 234 & 65,7 \\
\hline
\end{tabular}

Table 1 shows that the average age of respondents is 34 years, mostly (53.7\%) male gender. Most respondents> education levels $(68.8 \%)$ is higher education, namely high school and college. Most respondents (65.7\%) Smoking. The average age of respondents is 34 years which means that respondents are at a productive age. The age at which a person carries out activities regularly and works to make, most indonesians are at productive age (5). Respondents' knowledge of the dangers of smoking is categorized into two high and low knowledge shown in figure 1 .

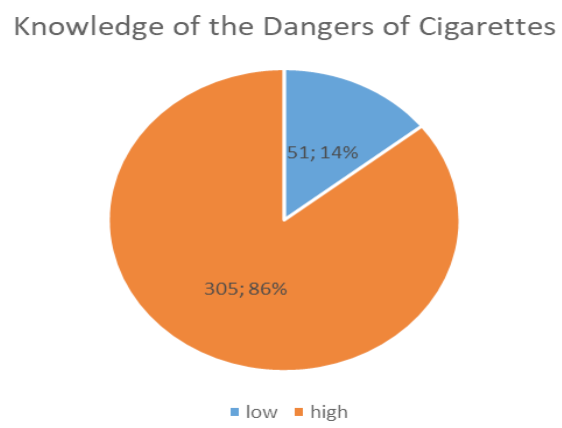

Figure 1. Pie Diagram Knowledge of the Dangers of Cigarettes 
Figure 1 shows that most (86\%) respondents' knowledge of the dangers of cigarettes is high, but there are still quite a lot of respondents $(34.3 \%)$ smoking (table 1). Knowledge of the high dangers of cigarettes was not followed by non-smoking behavior. The results of this study are not in line with Sairo's research (2017) which stated that IKAWASBA students' knowledge in Tlogomas Malang about the dangers of smoking is still mostly lacking (6). Knowledge is an important part of behavior. In this 4.0 era, people are so easy to access science through their gadgets including knowledge about the dangers of cigarettes. In addition, there are regulations on the obligation to convey the health message of the dangers of smoking on cigarette packs and cigarette advertisements so that the public can easily gain knowledge about the dangers of smoking. When the knowledge of the dangers of smoking is high then people should not smoke but in reality it has not been like that. The probable cause is that this smoking behavior is already considered a culture and lifestyle. Lifestyle has a big impact on decisions for smoking behavior (7).

To protect the public from the dangers of smoking the Government has regulated in Law No. 36 of 2009 on Health and Government Regulation No. 109 of 2012 on the safety of addictive substances including tobacco mentioned that the local government is obliged to establish a non-smoking area regulation, but there are still many areas (cities / districts) that do not have such regulations, for example in central Java province there are only 14 cities/districts that have smoke free law regulations. This study also explores public opinion about the existence of smoke free law with the results shown in figure 2.

Support The Existence of Non-Smoking Areas

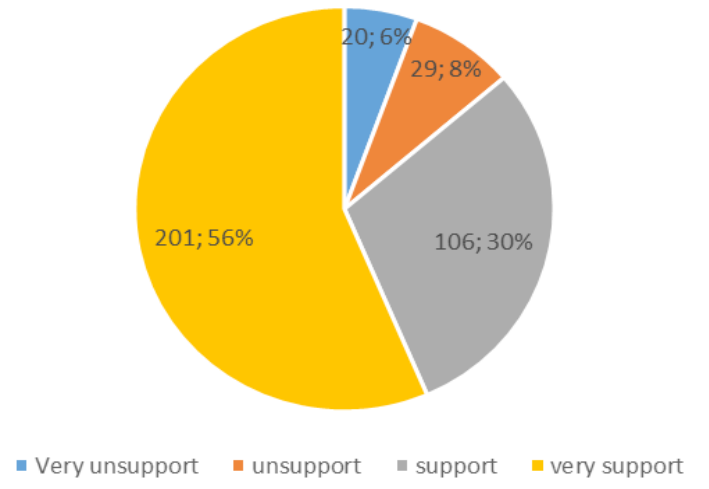

Figure 2. Pie Diagram Support The Existence of Non-Smoking Areas

Respondents strongly supported the existence of non-smoking areas as Azkha research in 2013 stated that the majority of people $(60 \%)$ regulation of smoke free law and smoke free law effectively to reduce active smokers. In order for smoke free law to be established and implemented, it is necessary to commit from local government and support from various parties including support from the community (8). Magelang 
City and Regency do not yet have a regional smoke free law, even though the community is very supportive. The city and magelang regency have been awarded as child-friendly cities even though they are still in the nidya category. One indicator of child-friendly cities is the existence of regulations on nonsmoking areas including the prohibition of advertising and sponsorship so as to prevent novice smokers. When you have tried to smoke, there will be a desire to smoke again because in tobacco there are nicotine substances that cause addiction for the user. In addition, nicotine also causes abnormalities in the heart and endocrine system. Nicotine increases pulse rate, increases contractility of heart muscle, blood pressure, causes narrowing of coronary blood vessels and respiratory disorders even nicotine also causes cancer (9). The cause of death in Indonesia has now shifted from infectious diseases to non-communicable diseases. One of the risk factors of non-communicable diseases is smoking behavior. Smoking behavior in the community is still quite high, including the number of novice smokers is increasing, one of the causes is the number of cigarette advertisements found. Figure 3 shows the opinion that cigarette advertising affects smoking.

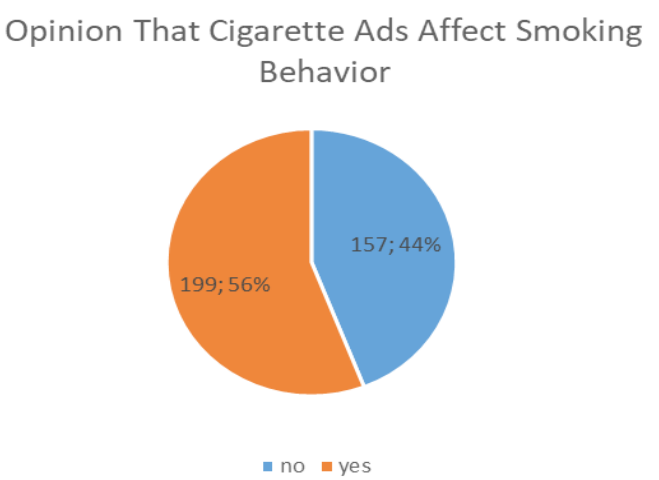

Figure 3. Pie Diagram Opinion That Cigarette Ads Affect Smoking Behavior

Most respondents argued that cigarette advertising influenced smoking behavior. Various studiesmention thatcigarette advertising gives rise to a person $>$ s desire to try smoking. The results of this study are in line with Purnaningrum $>$ s research (2017) that exposure to high cigarette advertising greatly influences smoking behavior. People who do not smoke become wanting to smoke, people who want to quit smoking become unable to quit smoking even people who have smoked become more and more smoking. Advertising is a very powerful promotional media in shaping public opinion, in this case the imagery of cigarette products (10). Cigarette ads featuring idol actors who seem cool, masculine, creative and even successfully face all obstacles by smoking make teenagers want to model smoking behavior. Teenagers who are in the form of identity will certainly be attracted by the positive image offered in cigarette advertising. 
Many media used by the cigarette industry to deliver advertisements about cigarettes include television, music concerts, sports events and others as directed in figure 4.

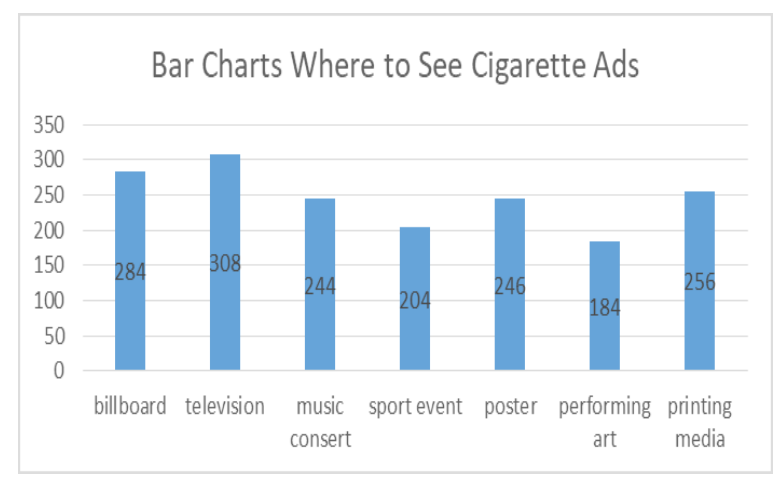

Figure 4. Bar Charts Where to See Cigarette Ads

Respondents saw the most cigarette advertisements from television, billboards, print media, music concert posters, posters, sports events and art performances. Advertising aims to create stereotypical value. Visual choices and how to combine them with text can create streotypes as quickly as possible, as widely as possible, and last as long as possible. Stereotypes on advertising become the key to changing consumer minds and behavior (11). Television is an ideal medium to advertise items that are always used every day, such as food products, cosmetics, medicine, cigarettes and so on because of its wide reach. Mthrough television media can make people see the product images and the sound of messages made by advertisers so that it feels more interesting and the message conveyed is clear, while through print media can only seethe image not by hearing the message delivered, and if through radio ads can only hear the message delivered but can not see the form of the product offered. In television ads to make the message delivered more quickly received and remembered by consumers is usually aired repeatedly with a short time (12). Thus, the policy of advertising cigarette products should be strictly enforced so as not to cause negative impacts from the community, especially the younger generation who are the next generation of the nation.

\section{CONCLUSIONS AND SUGGESTIONS}

Knowledge of the dangers of smoking although high but still found smoking behavior in respondents. However, respondents strongly supported the existence of nonsmoking regional policies. Respondents argued that cigarette advertising affects smoking behavior and most see cigarette advertisements on television so that the government should immediately realize regulations in the form of a comprehensive National Regulation and enforce them consistently by involving relevant parties. 


\section{ACKNOLEDGEMENT}

The study was supported by the International Union Against Tuberculosis and Lung Desease.

\section{REFERENCE}

Ministry of Health BP and PK. Basic Health Research. 2013;

Ministry of Health BP and PK. Key Results riskesdas 2018. 2018;

Sari SM, Afandi D, Fauzu ZA. Overview of Teacher Smoking Behavior in Junior High School Environment in New Week. JOM FK. 2015;2(1):1-12.

Puspawati PIAR, Kristina SARI, Ahsan A. The burden of living with cancer due to smoking in Indonesia: Years Lived with Disability (YLD). Journal of International Pharmaceutical Research. 2020;12(3).

BP Statistics. Indonesian Youth Statistics. 2014.

Sairo BB, Wiyono J, Adi W RC. Relationship of Knowledge About the dangers of smoking by Consuming Cigarettes In Students (IKAWASBA) in Tlogomas Malang City. Nursing News. 2017;2(2).
Bahtiar A, Rahardja E. Influence of Brand Equity, Price and Distribution on Vape Purchase Decisions (Study OnVape Store 5Time). Diponegoro Journal of Management. 2017;6(4):1-10.

Azkha N. Effectiveness Study of The Implementation of City Government Policy on Non-Smoking Areas (SMOKE FREE LAW) In An Effort to Reduce Active Smokers in West Sumatra In 2013. Indonesian Journal of Health Policy. 2013;02(04):171-9.

Bold KW, Krishnan-sarin S, Stoney CM. E-Cigarette Use as a Potential Cardiovascular Disease Risk Behavior. Am Psychol. 2018;73(8):955-67.

Purnaningrum WD, Joebagio H, Murti B. Association Between Cigarette Advertisement, Peer Group, Parental Education, Family Income, and Pocket Money with Smoking Behavior among Adolescents in Karanganyar District, Central Java. Journal of Health Promotion and Behavior. 2017;2(2):148-58.

Virga RL. Cigarette advertising literacy and consumptive behavior of adolescents through the empowerment of 
mosque youth. Prophetic Journal of Communication. 2016;09(02).

Jusuf CS, Hermanto DR. Is Still Strong Television Advertising
To Make Consumers In the Era of Technology, Communication and Information. Scientific Journal of Asian Business and Economics. 2019;13(1):37-45. 